\title{
Time to get real: The case for critical action research in purchasing and supply management
}

\author{
Journal of Purchasing and Supply Management
}

http://dx.doi.org/10.1016/j.pursup.2016.08.006

In fragile and often complex supply chains, PSM failures continue to be reported in the media, often with severe economic, social and environmental consequences. To encourage organisations to engage in responsible PSM, we need engaged research. In this paper we argue that Action Research (AR) is an influential, participative method to challenge the more dominant versions of PSM impacts, which tend to focus only on the positive, and often only monetised elements of what is valued. AR places change at the core of the research process, requiring critical reflexive practice of the impact of assumptions, values and actions on others. We argue that PSM research has more potential for influence if it starts from a 'real' problem anchored in practice, and that crucially, the problem itself should be challenged dialogically by scholars, practitioners and diverse stakeholders. Critical AR can reframe performance from a technical, company-centric notion to explore broader relationships between inputs and outputs over a longer time frame. We explore the risks and rewards of Critical AR for PSM scholars and draw conclusions on our role as engaged advocates of change.

Keywords

Action research

Critical management

Engaged research

Supply management research

Critical action research

Joanne Meehan, University of Liverpool Management School

Anne Touboulic, Nottingham University Business School

Helen Walker, Cardiff Business School

\section{Introduction}

As academic agendas move towards delivering impactful research there is a need to challenge the foundations of our knowledge. Conflicting pressures coexist in the 'publish or perish' academic culture that can wed scholars to methods considered less risky (Wensley, 2007), conflate dominant theories (Cova et al., 2009), and discourage longitudinal research approaches. As a result, a criticism of management research, including those in the 'top' journals, is that despite high rigour, papers have become formulaic, predictable, lacking in imagination (Alvesson et al., 2016) and the findings have low social impact (Bartunek et al., 
2006, Clark and Wright, 2009). Replication of normative methods runs the risks of practical irrelevance, failure to provide new insights, 
and a disengagement from organisations and society, where scholars are left reporting the agendas rather than leading and influencing them.

For our contribution to be sustainable and impactful our research should shape managerial thinking and engage with those affected by it. This demands coproduction of research (c.f. Martin, 2010) not just a superficial communication at the latter dissemination stages of a research project. Different methods are required to ask new questions of the underpinning assumptions in our dominant theories. In response to the academic impact agenda, there have been calls for more action-orientated methods in purchasing and supply chain research (Crespin-Mazet and Dontenwill, 2012, Pagell and Shevchenko, 2014, Touboulic and Walker, 2015, Touboulic and Walker, 2016, Walker et al., 2008a) not just to demonstrate methodological variety, but also to explore real practical issues (Coughlan and Coghlan, 2002, Gummesson, 2000, Näslund et al., 2010). Action research $(A R)$ is problem centred (Sanford, 1970), yet, should purchasing research aim to go further than exploring practical institutional and managerial problems?

\section{Impactful PSM}

Purchasing and supply management (PSM) is increasingly positioned as a critical business function with growing responsibilities related to organisational performance, supply chain risk and reputation (Giannakis, 2012, Zheng et al., 2007). With this increased responsibility comes accountability. The following examples bring into sharp focus the catastrophic social, environmental and financial impacts and myriad of unintended consequences that PSM failures can, and do have: The Rana Plaza disaster, the horsemeat food fraud, the diesel emissions scandal, working conditions at Apple's supplier Foxconn in China, the abuse of Cambodian garment factory workers in Nike and Walmart's supply chains, and the on-going environmental catastrophes in the Niger Delta from the petroleum industry.

Common in these examples are that PSM actions are grounded in traditional performance optimisation, profit-driven, organisation-centric thinking. Despite decades of academic research on relevant issues at the heart of addressing these failures, including buyer-seller relationships, partnerships, outsourcing and risk, failures are still happening. Is it that practitioners are not listening, or that our theories are not always fit-for-purpose? The theoretical foundations of PSM research have been described as weak and lacking in disciplinary maturity (Spina et al., 2016), suggesting that we need new theories and new methods that consider the complexity of contemporary organisational environments.

\section{The case for action research}

As PSM failures continue, we need to explore new research approaches if our impact on management practice is to be relevant and enduring. The development of contemporary theory is one of AR's core, explicit demands (Eden and Huxham, 1996). AR aims to challenge the status quo and originates from the need to solve practical, and complex social problems (Lewin, 1947). Recent AR research in the PSM field has explored problems related to sustainable practices in supply networks (Golob et al., 2014, Touboulic and Walker, 2015), decision making for New Product Development (Le Dain et al., 
2010), strategic supplier performance evaluation (Dey et al., 2015) and the establishment of direct and cheaper procurement processes (Pereira et al., 2011).

Although it is common for AR studies to be empirically situated in individual organisational contexts, AR seeks to move beyond the specific to the general to provide traction for change. As business environments increase in uncertainty and volatility, organisations require transparency through their supply chains to enable them to be adaptive to wider geo-political, environmental and social factors, where integration will be driven by behaviours (Stevens and Johnson, 2016). The complexity of these new challenges requires participatory approaches so we can adapt or develop PSM theories that reflect diverse stakeholder perspectives over time, challenge existing power structures, and increase the potential for change (Linton et al., 2007). The utility of abstracted theory development stems from the rich, powerful data in AR's practical, iterative empirical setting focused on systemic inter-relationships rather than singular perspectives of issues.

$A R$ is research 'in' action, rather than research 'about' action (Coughlan and Coghlan, 2002) and it encompasses a spectrum of approaches and influences (Cassell and Johnson, 2006). There is no definitive classification of AR as a methodology, and its diversity is embraced (Reason and Bradbury, 2008) as an umbrella research philosophy that views knowledge creation as a collaborative and dialectic process to 'make things happen' (Cassell et al., 2009). AR represents an opportunity for PSM scholars to address the 'double hurdles of scholarship and relevance' (Pettigrew, 2001, Van de Ven and Johnson, 2006). Mainstream research paradigms can lead scholars to be more preoccupied by methodological rigour than by the pursuit of interesting research and theory (Bartunek et al., 2006, Davis, 1971). The notion of rigour advocated by traditional methods is often rooted in distant observation and a replication-driven logic. Rigorous research is necessary but not sufficient for it to be influential. AR provides a way to re-humanise PSM research through the promotion of problemdriven approaches whose quality is not solely determined by the originality of theoretical insights but equally by their relevance and how research relationships are managed (Koplin, 2005).

\section{Critical action research}

Critical management scholars claim that academic research should aim to systematically challenge assumptions and thinking (Alvesson and Sandberg, 2011, Alvesson and Sandberg, 2013), rather than constructing narrow 'gapspotting' studies (Alvesson and Sandberg, 2011) that can be devoid of practice and fail to critique underpinning conventions. Critical approaches demand reflective interrogations of familiar positions to develop impactful research (Alvesson and Sandberg, 2011). AR is an influential method as it places change at the core of the research process, requiring critical reflexive practice of the impact of assumptions, values and actions on others (Cunliffe, 2004). We support critical management scholars but advance their call further to ensure PSM research is not just action-oriented, but also participatory. A stream within the critical management studies field aims to engage in dialogue with practitioners (Anthony, 1998, Watson, 1994) to transform management practice and restore a humanity to decision making (Fournier and Grey, 2000). 
We argue that PSM research has more potential for influence if it starts from a 'real' problem anchored in practice, and that crucially, the problem itself is challenged dialogically by scholars, practitioners and diverse stakeholders. Under a critical performative perspective, the notion of performance requires reframing and a radical re-imagining to move away from purely technical, company-centric values to judge relationships between inputs and outputs (Spicer et al., 2009). Engaged approaches allow issues to be seen from different perspectives, raising the consciousness of all involved in the research, and those potentially affected by it, as it aims to transform as well as predict and control (Saunders et al., 2009).

The danger here is that organisations, and PSM researchers, may only engage with traditional, commercially orientated network partners (Meehan and Bryde, 2015), and performance considerations persist in narrow terms. AR, in comparison seeks to promote a more democratic and inclusive approach to research in pursuit of sustainable change to minimise the risks of marginalising issues or groups though abstracted universal theories (Bondy and Starkey, 2014). Shifting the foundations of how the research problem is situated through AR is an important step for emancipatory change in PSM research and can provide a space for marginalised, less powerful voices to be heard. Emancipatory management is perhaps an oxymoron, but AR can encourage challenge to previously uncontested activities. Traditional non-action/engaged approaches can reinforce dominant paradigms and power structures in supply chains. AR considers a broader scope, over a longer time-frame (Walker et al., 2008b), that challenges the focus on company-centric internal initiatives (Touboulic and Walker, 2016). AR can provide an important source of social understanding and a much-needed impetus for social and political changes (Fay, 1987) through seeking counter-narratives to the more dominant versions of PSM impacts, which tend to focus only on the positive, and often only monetised elements of what is valued.

Critical AR approaches remain marginally represented in PSM research (Touboulic and Walker, 2016) and the role that individuals play in driving or resisting change is largely underexplored. While this may be a symptom of the influence of dominant paradigms in the field, it is important to acknowledge the limitations of AR. Longitudinal access and engagement can generate rich data but a critical reflexive distance is needed to prevent researchers becoming coopted (Johansson and Lindhult, 2008). Critical-reflexive AR researchers also need to consider how they can instigate the transformation of practice when access is not possible (Welford, 1997). This may involve engaging with unusual stakeholders who are also motivated by change or simply reflecting on the notion of change itself. Change may not necessarily imply radical transformation or utopian thinking; working closely with practitioners and opening dialogues on "un-discussed" issues can have powerful ripple effects. Thinking the unthinkable and exploring potential impacts of present actions compared with alternatives provides valuable space for considered decisionmaking and providing accountability.

\section{Concluding thoughts}

Critical AR presents risks and rewards for PSM scholars. AR allows an exploration of real world problems in a reflexive and critical way, through engaged and participatory research that is impactful. It can generate practical solutions 
that people buy in to, as well as allowing researchers to generate new theories through the insights gained from in-depth questioning of PSM issues. For the PSM discipline, conducting AR will have implications for how we perform as scholars. AR will take longer and may lead to less journal outputs than, say, survey research. However, it is more likely to have an impact, as it requires engagement with multiple stakeholders over time. Critical AR may meet resistance from some journals with more traditional methodical orientations, but the depth and criticality of research is likely to lead to theoretical innovations and sustainable change in organisational practice.

A more political question for PSM scholars is whether we can afford not to engage with those supply chain actors most affected by PSM activities? We may need to rethink our roles as researchers. We have choices whether to turn a blind eye and passively support harmful practices without critiquing them, and whether to represent the views of less powerful actors in the supply chain. If we want to encourage organisations to engage in responsible PSM, we need to stop being disengaged researchers, and embrace our role as advocates. Rather than pursuing a traditional neutral tone, we may need to take a normative position regarding the 'shoulds' and 'oughts' of responsible PSM. Moving scholars towards advocacy (Eisenberg, 1993) and critical approaches potentially underlines further the need for longitudinal, iterative and reflexive emergent theory development. AR has a specific focus on action and finding practical answers (Cassell and Johnson, 2006, Coughlan and Coghlan, 2002), yet if we seek to redefine debates, ask different questions, challenge assumptions and, importantly, recommend particular choices amongst other competing options, scholars need to simultaneously take time to reflect, and theorise to ask the 'big' questions, even those without obvious practical answers (Fleming and Banerjee, 2016).

Challenging the assumptions of our knowledge base and developing theories appropriate for emerging issues has wider implications for how scholars encourage critical reflexivity in the education of PSM practitioners and in our professional associations. A delicate balance needs to be found, for if scholars are overly critical of present systems and the organisational order, it can create a barrier to engaging with decision makers (Fleming and Banerjee, 2016) - the very people we might seek to influence.

ALVESSON, M. \& SANDBERG, J. 2011. Generating research questions through problematization. Academy of management review, 36, 247-271.

ALVESSON, M. \& SANDBERG, J. 2013. Has management studies lost its way? Ideas for more imaginative and innovative research. Journal of Management Studies, 50, 128-152. 
ALVESSON, M., SPICER, A., MAGALA, S. \& MAGALA, S. 2016. (Un) Conditional surrender? Why do professionals willingly comply with managerialism. Journal of Organizational Change Management, 29, 29-45.

ANTHONY, P. 1998. Management Education: Ethics versus Morality. In: M.PARKER (ed.) Ethics and organization. London: Sage.

BARTUNEK, J. M., RYNES, S. L. \& IRELAND, R. D. 2006. What makes management research interesting, and why does it matter? Academy of management Journal, 49, 9-15.

BONDY, K. \& STARKEY, K. 2014. The dilemmas of internationalization: corporate social responsibility in the multinational corporation. British Journal of Management, 25, 4-22.

CASSELL, C., BISHOP, V., SYMON, G., JOHNSON, P. \& BUEHRING, A. 2009. Learning to be a Qualitative Management Researcher. Management Learning, 40, 513-533.

CASSELL, C. \& JOHNSON, P. 2006. Action research: Explaining the diversity. Human Relations, 59, 783-814.

CLARK, T. \& WRIGHT, M. 2009. So, farewell then... reflections on editing the Journal of Management Studies. Journal of Management Studies, 46, 1-9.

COUGHLAN, P. \& COGHLAN, D. 2002. Action research for operations management. International Journal of Operations and Production Management, 22, 220240.

COVA, B., FORD, D. \& SALLE, R. 2009. Academic brands and their impact on scientific endeavour: The case of business market research and researchers. Industrial Marketing Management, 38, 570-576.

CRESPIN-MAZET, F. \& DONTENWILL, E. 2012. Sustainable procurement: Building legitimacy in the supply network. Journal of Purchasing and Supply Management, 18, 207-217.

CUNLIFFE, A. L. 2004. On becoming a critically reflexive practitioner. Journal of Management Education, 28, 407-426.

DAVIS, M. S. 1971. That's interesting. Philosophy of the Social Sciences, 1, 309.

DEY, P. K., BHATTACHARYA, A. \& HO, W. 2015. Strategic supplier performance evaluation: a case-based action research of a UK manufacturing organisation. International Journal of Production Economics, 166, 192-214.

EDEN, C. \& HUXHAM, C. 1996. Action research for management research. British Journal of Management, 7, 75-86.

EISENBERG, R. S. 1993. The Scholar as Advocate. Journal of Legal Education, 43, 391-400.

FAY, B. 1987. Critical Social Science: Liberation and its Limits, Cambridge, UK, Polity.

FLEMING, P. \& BANERJEE, S. B. 2016. When performativity fails: Implications for critical management studies. human relations, 69, 257-276.

FOURNIER, V. \& GREY, C. 2000. At the critical moment: Conditions and prospects for critical management studies. Human relations, 53, 7-32.

GIANNAKIS, M. 2012. The contribution of purchasing to the management of supplier relationships: the mediating role of asset specificity and criticality of the exchanged offerings. International Journal of Integrated Supply Management, 7, 80-113.

GOLOB, U., JOHANSEN, T. S., NIELSEN, A. E. \& PODNAR, K. 2014. Corporate Social Responsibility as a messy problem: Linking systems and sensemaking perspectives. Systemic Practice and Action Research, 27, 363-376.

GUMMESSON, E. 2000. Qualitative Methods in Management Research, London, Sage Publications.

JOHANSSON, A. W. \& LINDHULT, E. 2008. Emancipation or workability? Critical versus pragmatic scientific orientation in action research. Action Research, 6, 95-115. 
KOPLIN, J. 2005. Integrating environmental and social standards into supply management: An action research project In: KOTZAB, H., SEURING, S., MÜLLER, M. \& REINER, G. (eds.) Research Methodologies in Supply Chain Management. Heidelberg: Physica-Verlag.

LE DAIN, M.-A., CALVI, R. \& CHERITI, S. 2010. Developing an approach for designor-buy-design decision-making. Journal of Purchasing and Supply Management, 16, 77-87.

LEWIN, K. 1947. Frontiers in Group Dynamics: Concept, Method and Reality in Social Science; Social Equilibria and Social Change. Human Relations, 1, 541.

LINTON, J. D., KLASSEN, R. \& JAYARAMAN, V. 2007. Sustainable supply chains: An introduction. Journal of Operations Management, 25, 1075-1082.

MARTIN, S. 2010. Co-production of social research: strategies for engaged scholarship. Public Money \& Management, 30, 211-218.

MEEHAN, J. \& BRYDE, D. J. 2015. A field-level examination of the adoption of sustainable procurement in the social housing sector. International Journal of Operations \& Production Management, 35, 982-1004.

NÄSLUND, D., KALE, R. \& PAULRAJ, A. 2010. Action research in supply chain management-a framework for relevant and rigorous research. Journal of Business Logistics, 31, 331-355.

PAGELL, M. \& SHEVCHENKO, A. 2014. Why research in sustainable supply chain management should have no future. Journal of Supply Chain Management, 50, 44-55.

PEREIRA, G. M., SELLITTO, M. A., BORCHARDT, M. \& GEIGER, A. 2011. Procurement cost reduction for customized non-critical items in an automotive supply chain: An action research project. Industrial Marketing Management, 40, 28-35.

PETTIGREW, A. M. 2001. Management research after modernism. British Journal of Management, 12, 61-70.

REASON, P. \& BRADBURY, H. (eds.) 2008. The Sage Handbook of Action Research London: Sage.

SANFORD, N. 1970. Whatever happened to action research? Journal of social issues, 26, 3-23.

SAUNDERS, M., LEWIS, P. \& THORNHILL, A. 2009. Research methods for business students, Harlow, Pearson.

SPICER, A., ALVESSON, M. \& KÄRREMAN, D. 2009. Critical performativity: The unfinished business of critical management studies. Human relations, 62, 537-560.

SPINA, G., CANIATO, F., LUZZINI, D. \& RONCHI, S. 2016. Assessing the use of external grand theories in purchasing and supply management research. Journal of Purchasing and Supply Management, 22, 18-30.

STEVENS, G. C. \& JOHNSON, M. 2016. Integrating the Supply Chain ... 25 years on. International Journal of Physical Distribution \& Logistics Management, , 46, 19-42.

TOUBOULIC, A. \& WALKER, H. 2015. Love me, love me not: A nuanced view on collaboration in sustainable supply chains. Journal of Purchasing \& Supply Management, 21, 178-191.

TOUBOULIC, A. \& WALKER, H. 2016. A relational, transformative and engaged approach to sustainable supply chain management: the potential of action research. Human Relations, 69, 301-343.

VAN DE VEN, A. H. \& JOHNSON, P. E. 2006. Knowledge for theory and practice. Academy of management review, 31, 802-821.

WALKER, H., DI SISTO, L. \& MCBAIN, D. 2008a. Drivers and barriers to environmental supply chain management practices: Lessons from the public 
and private sectors. Journal of Purchasing and Supply Management, 14, 6985.

WALKER, H., HARLAND, C., KNIGHT, L., UDEN, C. \& FORREST, S. 2008b.

Reflections on longitudinal action research with the English National Health Service. Journal of Purchasing and Supply Management, 14, 136-145.

WATSON, T. 1994. In search of management, London, Routledge.

WELFORD, R. 1997. Corporate environmental management 2: culture and organisations, London, Earthscan/James \& James.

WENSLEY, R. 2007. Beyond rigour and relevance: The underlying nature of both business schools and management research. Advanced Institute of Management Working Paper.

ZHENG, J., KNIGHT, L., HARLAND, C., HUMBY, S. \& JAMES, K. 2007. An analysis of research into the future of purchasing and supply management. Journal of Purchasing and Supply Management, 13, 69-83. 